\title{
Phylogenetic Framework and Metabolic Genes Expression Analysis of Bacteria Isolated from Contaminated Marine Environments of Niger Delta
}

\author{
Bright Obidinma Uba ${ }^{{ }^{*}}$ \\ ${ }^{1}$ Department of Microbiology, Chukwuemeka Odumegwu Ojukwu University, P.M.B. 02 Uli, \\ Anambra State, Nigeria. \\ Author's contribution \\ The sole author designed, analysed, interpreted and prepared the manuscript. \\ Article Information \\ DOI: 10.9734/ARRB/2018/v30i530023 \\ Editor(s): \\ (1) Dr. George Perry, Dean and Professor of Biology, University of Texas at San Antonio, USA. \\ Reviewers: \\ (1) Noor Ul Akbar, Kohat University of Science and Technology, Pakistan. \\ (2) Dr. M. Thangaraj, Annamalai University, India. \\ Complete Peer review History: http://www.sdiarticle3.com/review-history/46533
}

Original Research Article

Received 01 November 2018

Accepted 17 January 2019

Published 13 March 2019

\section{ABSTRACT}

Aims: To explore the phylogenetic framework of bacteria isolated from contaminated marine environments of Niger Delta and the expression of the metabolic genes coding for aromatic hydrocarbon degradation and surfactant production.

Study Design: Nine treatments designs were set up in triplicates containing $25 \mathrm{~mL}$ of sterile modified mineral basal medium supplemented with nine marine hydrocarbon degraders incubated at $24^{\circ} \mathrm{C}$ for 5 days. Three of the set ups were supplemented each with $1 \mathrm{mg} / \mathrm{L}$ of xylene, anthracene and pyrene.

Place and Duration of Study: Department of Environmental Sciences, University of South Africa, Pretoria, South Africa between September, 2015 to December, 2017.

Methodology: A laboratory scale study was carried on six composite samples of the sediment and water samples from the three studied areas using enrichment, screening, selection, characterization, and PCR assays to explore the phylogenetic framework and metabolic genes expression of the marine bacteria for aromatic hydrocarbon degradation and surfactant production. Results: The findings revealed that there was significant abundance of THB $(P=.05)$ more than TCHUB and more xylene degraders than anthracene and pyrene degraders in the sediment and 
water samples respectively. The phylogenetic correlational analysis revealed that all the nine selected best degraders out of 48 isolates from the studied area were evolutionary related belonging to the genera: Providencia, Alcaligenes, Brevundimonas, Myroides, Serratia, and Bacillus; able to significantly $(P=.05)$ utilize the all the aromatic hydrocarbons. The existence of catabolic and surfactant genes namely catechol dioxygenase (C23O), rhamnolipid enzyme (rhIB) and surfactin /lichenysin enzyme (SrfA3 /LicA3) genes were detected in only four (4) out of the nine (9) marine aromatic degrading bacteria with 881 base pairs sizes.

Conclusion: Thus, the study revealed that these bacterial strains especially Serratia marcescens XYL7 might possess metabolic genes for in situ aromatic hydrocarbon degradation and surfactant production.

Keywords: Aromatic hydrocarbons; biodegradation; biodiversity; catabolic genes; marine bacteria; Niger Delta; surfactant genes.

\section{INTRODUCTION}

The Niger Delta region is the centre of petroleum exploration, production and development accomplishments in Nigeria. Several cases of oil spills have been reported thereby promoting and increasing the pollution of the Niger Delta's aquatic and terrestrial environments. These spills have been associated with disruption, deterioration of pipes, negligence, mishaps during oil exploitation, production, rupture of storage tanks and accidents brought about by transportation [1]. Most of these compounds especially the aromatic hydrocarbons are considered as toxicants and are classified as priority environmental pollutants by the US Environmental Protection Agency [2].

Biodiversity is the result of evolution that occur billions of years ago leading to multiplicity of species of living organisms on the earth. Molecular phylogenetic studies have shown that the chief diversity of life is in the microbial world and it is circulated amongst the three main domains: eubacteria, eukarya, and archaea. The methods of single cell sequencing, metatranscriptomics, metaproteomics and metagenomics are used not only to reveal the community structure (species taxonomy, abundance and distribution) but also of the useful and biological niche of a community [3]. Most of biotechnological products such as biosurfactants, antibiotics, compatible solutes, exoplolysacccharides, enzymes etcetera with enormous medical, environmental and industrial uses are obtained from microbes of marine ecosystems or sources. This has attracted significant attention and interest on the marine bacteria as they produces novel metabolites of diverse applications than the terrestrial and other sources. Several reports have implicated marine bacteria in the production of metabolites such as surfactant that have purposeful and useful roles in bioremediation especially in the aspect of enhanced oil recovery [4].

As polluted sites are contaminated by a mixture of PAHs and other environmental contaminants [4], considerable investigation has concentrated on the bioremediation of aromatics hydrocarbons (Ahs) through metabolism and co-metabolism. The mechanism of degradation process chiefly involves enzyme machinery: dehalogenases, dehydrogenases, oxygenases and hydrolases system [5]. Thus, for an effectual remediation process to exist, it is imperative that the bacteria involved should have a comprehensive degradation pathway so that no possible noxious metabolites accrue [6]. Researches have shown that a cluster of genes for whole degradation of aromatic compounds are found in several PAH degrading bacteria through genetic analyses of PAH catabolic pathways. The diversity of aromatic-dioxygenase genes in several $\mathrm{PAH}$ degrading bacterial isolates have been studied through PCR amplification using genes specific primers or degenerate primers to revealed them [4]. Even though numerous bacteria capable of degrading PAHs have already been isolated and documented, it is still important to search, monitor and select more efficient and potent strains especially of the marine origin that can absolutely and rapidly mineralize PAHs under the deplorable and unfriendly environmental conditions of Niger Delta. Thus, exploring the phylogenetic markers such as 16S rRNA genes to disclose the microbial diversity and further investigation of gene expression to unveil the metabolic power of the marine microbes in the Niger Delta is essential. Therefore, the aim of the present study was to explore the phylogenetic framework of bacteria isolated from contaminated marine environments of Niger Delta and the expression of the metabolic genes 
coding for aromatic hydrocarbon degradation and surfactant production.

\section{MATERIALS AND METHODS}

\subsection{Description of the Sampling Sites}

The studied areas were Abonema Wharf Water Front (Fig. 1) in Akuku-Toru Local Government Area, Nembe Water-side (Fig. 2) in Port Harcourt Local Government Area and Onne Light Flow Terminal Seaport (Fig. 3) located in Eleme Local Government Area of Rivers State. Abonema town is $53 \mathrm{Km}$ and Abonema Wharf Water Front is $3-5 \mathrm{Km}$ from Port Harcourt capital city; Nembe water side is located within Port Harcourt capital city of Rivers State, while Onne Light Flow Terminal is about $35 \mathrm{Km}$ east from Port Harcourt capital city of Rivers State and $7 \mathrm{~km}$ from Onne town. These sites were geo referenced using Handheld Global Positioning System (GPS) GPSMAP 76 sc with the coordinates obtained from the sampling points or positions. Abonema Wharf Water Front, Nembe Water-side and Onne Light Flow Terminal Seaport were located between latitude $4^{\circ} 46^{\prime} 15.82^{\prime \prime} \mathrm{N}$ to latitude $4^{\circ} 46^{\prime} 38.01 " \mathrm{~N}$ and longitude $7^{\circ} 0^{\prime} 0.54 " \mathrm{E}$ to longitude $7^{\circ} 0^{\prime} 34.82 \mathrm{E}$ with average elevation of $4.1 \mathrm{~m}$, latitude $4^{\circ} 45^{\prime} 8.72 " \mathrm{~N}$ to latitude $4^{\circ} 45^{\prime} 26.42^{\prime \prime} \mathrm{N}$ and longitude $7^{\circ} 11^{\prime} 11.37 " \mathrm{E}$ to longitude $7^{\circ} 2^{\prime} 14.54 " \mathrm{E}$ with average elevation of $2.7 \mathrm{~m}$ and latitude $4^{\circ} 41^{\prime} 32.58 \mathrm{~N} \mathrm{~N}$ and $4^{\circ} 41^{\prime} 58.18 \mathrm{~N} \mathrm{~N}$ and longitude $7^{\circ} 9^{\prime} 26.34 " \mathrm{E}$ and $7^{\circ} 10^{\prime} 48.82^{\prime \prime} \mathrm{E}$ with average elevation of $2.3 \mathrm{~m}$, respectively. These water ways are subjected to anthropological - induced stresses brought about by expansion, industrial development and rigorous transportation. Abonema Wharf Water Front community is a popular and busy commercial but dangerous jetty area close to Port Harcourt city inhabiting tens of thousands of different families living close to petroleum tank farms and tankers queue up daily to load refined petroleum products. Nembe Waterside is located adjacent to Creek Road Market, Port Harcourt, Nigeria. It shares boundary with Bayelsa and connects Port Harcourt city with Bonny Island where greater percentage of petroleum connections in Rivers State are located. Also, it connects the Island straight to the Atlantic Ocean where petroleum is shipped by gigantic oil vessels [7]. Onne Light Flow Terminal Seaport is a port of Nigeria and the leading petroleum and gas unrestricted zone in the world supportive of exploration and production for Nigerian accomplishments. It is located on the Bonny River Estuary beside Ogu
Creek and accounts for more than $65 \%$ of the export cargo through the Nigerian Sea Port. Anthropological survey revealed the presence of human activities such as transportation of petrochemical products through tankers, canoes, boats and ships to neighboring villages, towns, cities, states and nations due to the presence of multinational petrochemical and oil servicing industries such as Chevron Nigeria Limited, Cameron Offshore services, Exxon Mobil Nigeria Limited, Socotherm Pipecoaters, Beker Hughes Oil Servicing Company, Aiteo Energy Resource, Sorelink Oil and Dozzy Oil and gas etcetera that generate the wastes that contaminate the sites above.

\subsection{Collection and Processing of Sample}

Ten samples each of the marine sediment and water were collected randomly per point of the designated ten (10) points of the three sampling sites (Figs. 1, 2 and 3). The samplings were done once in each of the three sampling sites in September, 2015. The samples were mixed together after which a total of six composite /representative sediment and water samples were obtained and taken for the analysis. The surface aerobic sediment samples were collected with a $95 \%$ ethanol - sanitized plastic spatula at 5 $\mathrm{cm}$ depth inside $95 \%$ ethanol - sanitized wide mouthed plastic containers. The water samples were collected at the air-water interface by hand dipping the $95 \%$ ethanol - sanitized cylindrical shaped $2 \mathrm{~L}$ plastic containers. The containers were rinsed with the sediment and water samples before collecting the samples. All the composite or representative sediment and water samples containers were placed into a sterile polythene bag and then transported to the Microbiology Laboratory, Chukwuemeka Odumegwu University, Uli Campus, Nigeria for microbiological analyses [8-10].

\subsection{Enrichment, Culturing and Isolation of Aromatic Hydrocarbon Degrading Bacterial Strains}

The hydrocarbon degraders were isolated from sediment and water samples of the three sampling sites using modified mineral basal agar

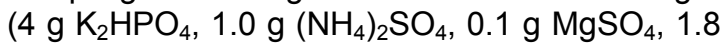
$\mathrm{g} \mathrm{KH}_{2} \mathrm{PO}_{4}, 0.1 \mathrm{~g} \mathrm{FeSO}_{4}, 0.1 \mathrm{~g} \mathrm{NaCl}, 0.2 \mathrm{~g} \mathrm{CaCl}_{2}$, $15 \mathrm{~g}$ Agar agar and distilled water $1,000 \mathrm{~mL}$ at $\mathrm{pH} 7.00 \pm 0.20$ ) enriched with xylene, anthracene and pyrene aromatic hydrocarbons. Sterilization of the medium was done by autoclaving at $121^{\circ} \mathrm{C}$ and $15 \mathrm{psi}$ for 15 minutes. Thereafter, $0.2 \mathrm{~mL}$ 
acetone solution containing $0.1 \%$ of the selected hydrocarbons (xylene, anthracene and pyrene) were aseptically pipetted and spread on the surface of the agar contained in Petri dish plates. The acetone was allowed to evaporate aseptically and $0.1 \mathrm{~mL}$ aliquots of the $10^{-3}$ dilutions were plated on the solidified media with a glass spreader. The spreader was sterilized after each successive spreading by dipping it in $70 \%$ ethanol and then passing it through flame of a Bunsen burner. The inoculated plates were sealed using adhesive tape and foil to prevent contamination and photolysis and later placed in black polythene bags, and then incubated in the dark at $28.00 \pm 0.20^{\circ} \mathrm{C}$ for 14 days. Also, Nutrient agar plates without hydrocarbons were inoculated and incubated at $28.00 \pm 0.20^{\circ} \mathrm{C}$ for $24-48$ hrs $[7,10-12]$.

\subsection{Total Viable Count Technique}

\subsubsection{Determination of total non-hydrocarbon - utilizing bacteria (TNHUB)}

The spread plate technique was used to determine the total non - hydrocarbon - utilizing bacteria on Nutrient agar. All the plates yielding 30 - 300 colonies were counted and the average number of colonies per plates were determined. The number of total heterotrophic bacteria was expressed at CFU $/ \mathrm{g}$ and CFU /mL [7, 12-15].

\subsubsection{Determination of total viable hydrocarbon - utilizing bacteria (TVHUB)}

Following the technique described above, total viable hydrocarbon - utilizing bacteria were determined on the modified mineral basal medium. All the plates yielding $30-300$ colonies were counted, the average number of colonies per plates were determined and expressed at $\mathrm{CFU} / \mathrm{g}$ and CFU /mL $[7,12,14]$.

\subsection{Purification and Maintenance of Cultures}

Colonies that developed on hydrocarbon enriched plates were duplicated onto new hydrocarbon enriched plates and incubated at $28.00 \pm 0.20^{\circ} \mathrm{C}$ for 14 days. The newly developed colonies were carefully chosen as xylene, anthracene and pyrene degraders and finally sub - cultured on Bijou bottles where they are preserved at $4^{\circ} \mathrm{C}$ in refrigerator [10].

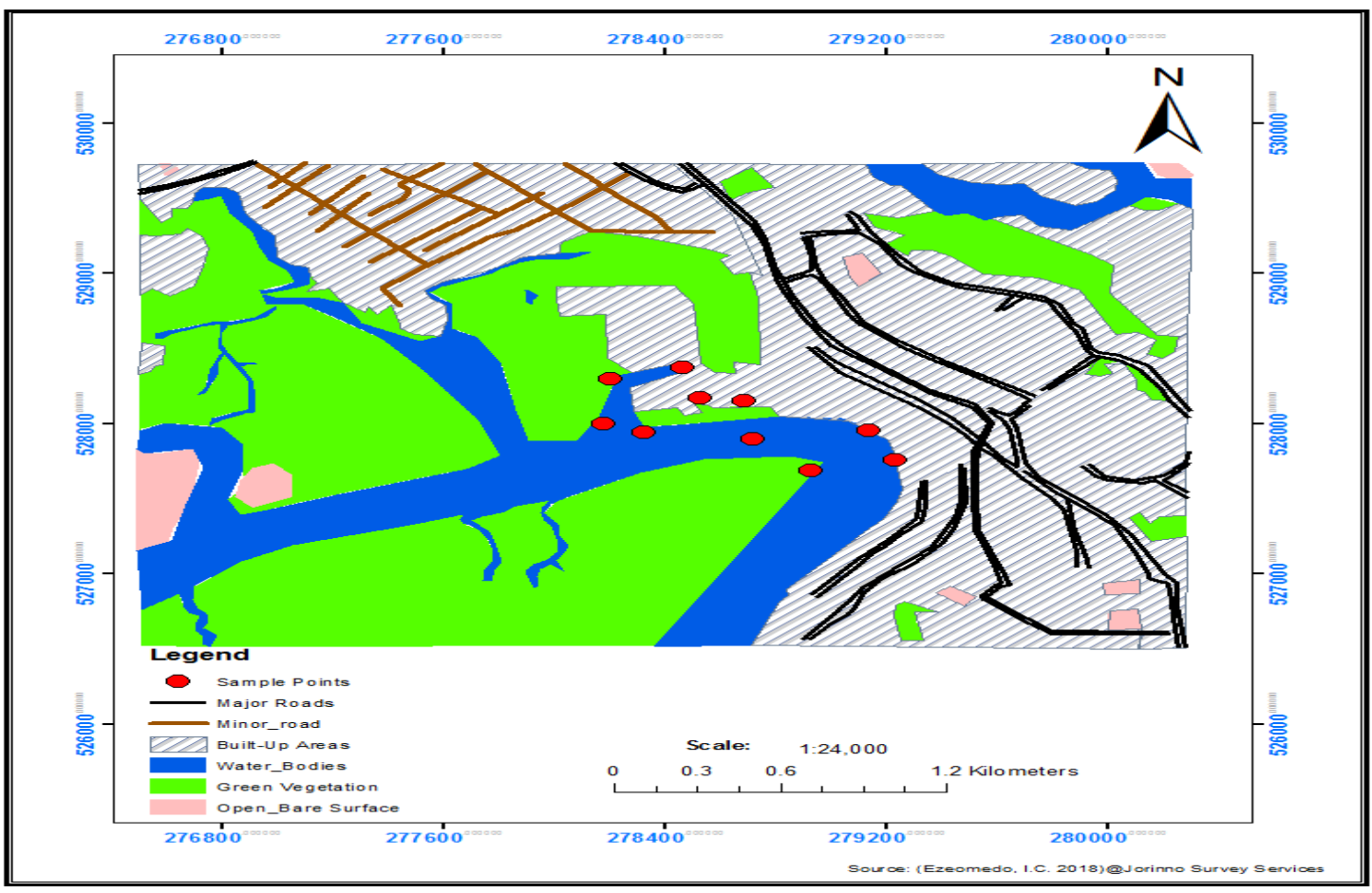

Fig. 1. Thematic map indicating the locations of sample points and its land cover in Abonema study area 


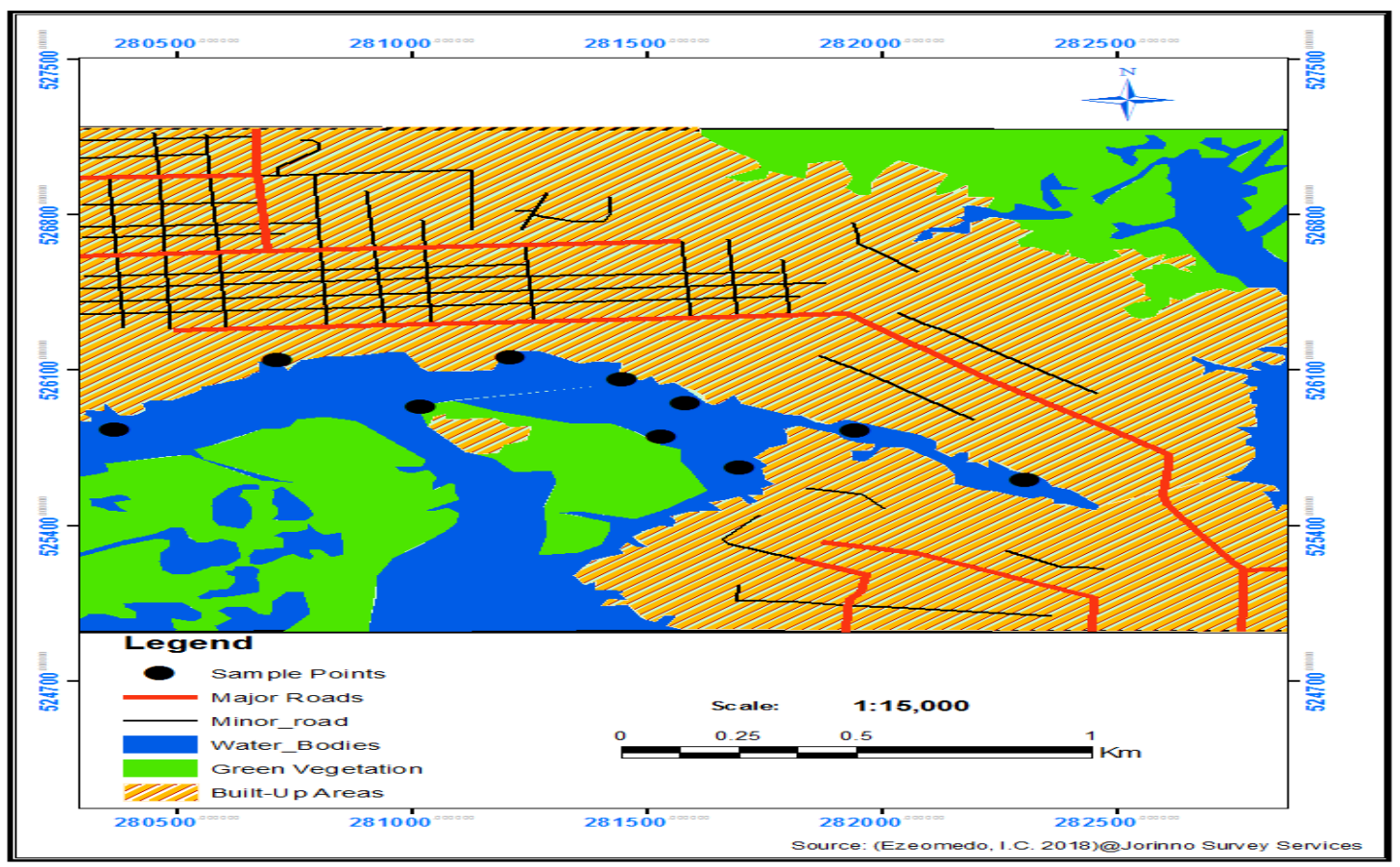

Fig. 2. Thematic map indicating the locations of sample points and its land cover in Nembe study area

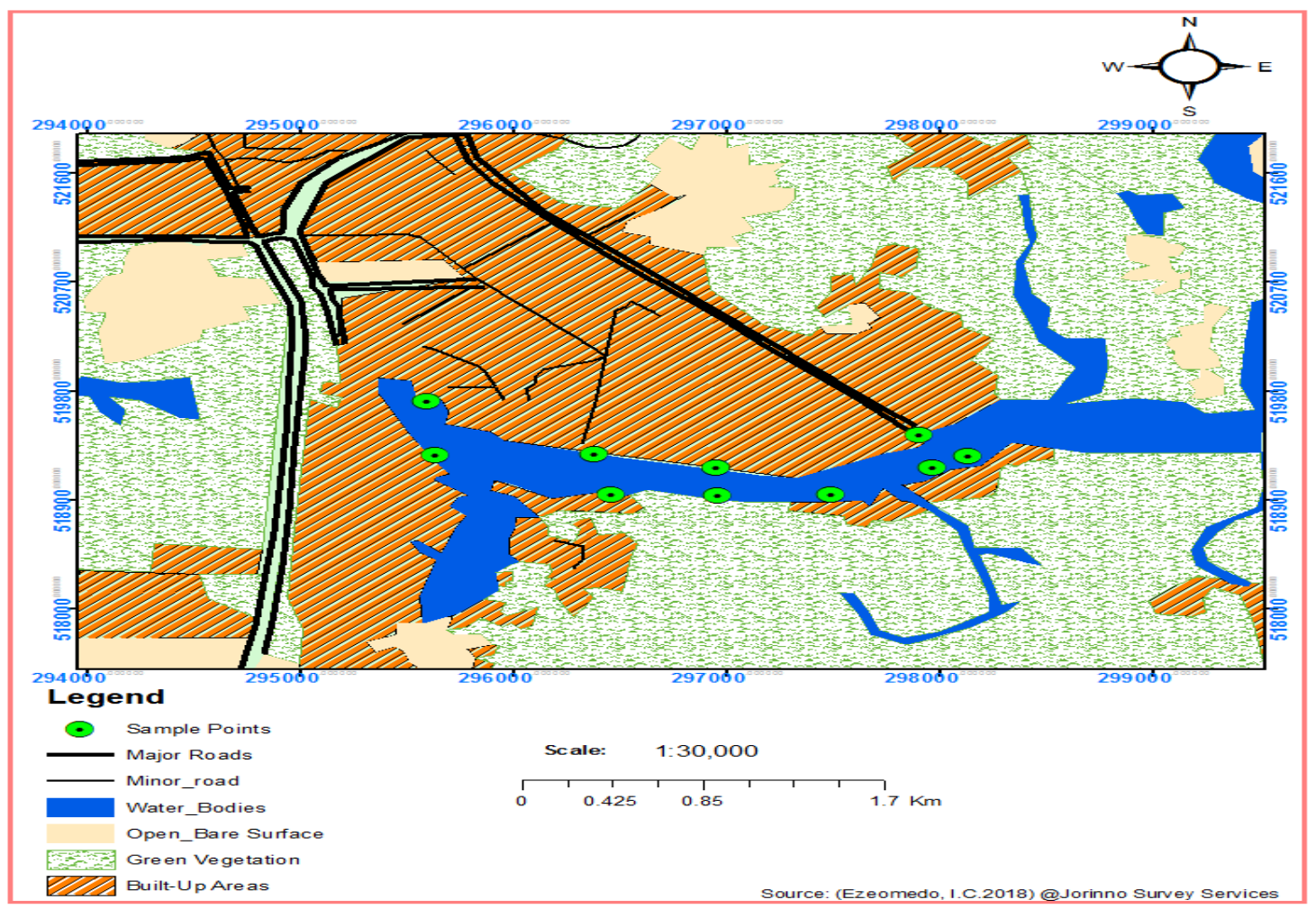

Fig. 3. Thematic map indicating the locations of sample points and its land cover in Onne study area 


\subsection{Screening and Selection Test}

In order to screen and select the best and strongest degrading strains, the bacterial isolates were grown using $5 \mathrm{~mL}$ of all the isolates in test tubes comprising $25 \mathrm{~mL}$ of the modified mineral basal medium supplemented with 100 ppm of xylene, anthracene and pyrene hydrocarbons as described in sub-section 2.3 above. Thereafter, the set ups were incubated at $28.00 \pm 2.00^{\circ} \mathrm{C}$ for five days. Bacteria that started growing fast with high turbidity in the vicinity of the medium containing aromatic compounds, quantified at $600 \mathrm{~nm}$ using a UV - VIS spectrophotometer (Astell, UV - Vis Grating, 752 W) were selected as xylene, anthracene and pyrene degraders [10, $16,17]$.

\subsection{Characterization and Identification of Selected Hydrocarbon Utilizing Bacterial Isolates}

\subsubsection{Molecular characteristics}

\subsubsection{Identification of bacteria}

The Gram - reaction test was first used to verify the morphological characterization of the bacterial colonies prior to molecular identification [18].

\subsubsection{Genomic DNA extraction of the bacterial isolates}

DNA extraction was conducted using conventional method of Cetyltrimethyl Ammonium Bromide (CTAB) protocol in sterile Eppendorf tubes. The DNA was separated electrophoretically with $1 \%$ agarose gel containing $0.1 \mu \mathrm{g} / \mathrm{mL}$ of ethidium bromide stain. The $20 \mathrm{~cm}$ long gels were ran at $80 \mathrm{~V} / \mathrm{cm}$ for 60 minutes in $100 \mathrm{~mL}$ of $1 \mathrm{x}$ tris acetate EDTA (TAE) electrophoresis buffer. The DNA was visualised by UV fluorescence to determine the success of the extraction process [18].

\subsubsection{Polymerase chain reaction (PCR) and sequencing of the extracted DNA}

The master mix aliquot for the PCR was dispensed into individual PCR tube and the different DNA samples were added to each tubes. The negative control was used to check for contamination in the master mix. The PCR reagents in each tube amounted to $50 \mu \mathrm{L}$ containing: buffer $(5 \mu \mathrm{L}), \mathrm{MgCl}_{2} \quad(1.5 \mu \mathrm{L})$, primer 1 (forward 16S - P1 PCR 5 -
AGAGTTTGATCCTGGCTCAG - $\left.3^{\prime}\right)(2 \mu \mathrm{L})$, primer 2 (reverse 16S - P2 PCR $5^{\prime}$. AAGGAGGTGATCCAGCCGCA - $\left.3^{\prime}\right)(2 \mu \mathrm{L})$, dNTP mix $(1 \mu \mathrm{L})$, Dream Taq $(0.25 \mu \mathrm{L})$, sterile sabax water $(35.25 \mu \mathrm{L})$ and purified DNA samples $(3 \mu \mathrm{L})$. The PCR reactions was performed using MJ Mini thermal cycler (BioRad, Hercules, CA, USA). The cycling conditions were set at (a) initial denaturation 10 minutes at $95^{\circ} \mathrm{C}$ for 1 cycle. (b) Denaturation at $95^{\circ} \mathrm{C}$ for 30 seconds, (c) Annealing cycling at $94^{\circ} \mathrm{C}$ for 30 seconds, (d) Elongation at $54^{\circ} \mathrm{C}$ for 2 minutes. All steps in denaturation, annealing and elongation was for 35 cycles and (e) final elongation 10 minutes at $72^{\circ} \mathrm{C}$ for 1 cycle. The reaction was held at $4^{\circ} \mathrm{C}$ for $1 \mathrm{hr}$ in the thermal cycler. The The PCR products (genes) were separated at $1 \mathrm{kbp}$ size and visualized as stated above (Fig. 1) [18]. Then the PCR products $(20$ $\mu \mathrm{L}$ each) were cleaned up later using $160 \mu \mathrm{L}$ of $13 \%$ polyethylene glycol (PEG) $8000,20 \mu \mathrm{L}$ of 5 $\mathrm{M} \mathrm{NaCl}$ solution and $200 \mu \mathrm{L}$ of $70 \%$ ethanol. The cleaned PCR products were sent for sequencing and was conducted using the automated DNA sequencer (Perkin-Elmer) in line with the sequencing kit protocol at the Forestry and Agricultural Biotechnology Institute (FABI) Sequencing Facility, University of Pretoria, South Africa [18].

\subsubsection{Blasting and phylogenetic correctional analyses}

The blasting of DNA sequences was performed by revising the sequences of the 16S rRNA genes obtained using BioEdit software, corrected sequences duplicated in a FASTA format form and completed in the National Centre for Biotechnology Information (NCBI) website. Homologies of the gene sequences were checked and compared with the sequences of the NCBI database and finally aligned using MAFFT software [19]. The taxonomic correctional studies were done using Mega 7 software and evolutionary distance of the isolates were calculated using neighbour - joining (NJ) methods $[4,15,18,19]$.

\subsubsection{GenBank accession number}

NCBI accession numbers were assigned to the nine selected aromatic hydrocarbon degrading bacterial strains and the nucleotide sequence details of 16S rRNA genes of these strains have been submitted to the NCBI /GenBank database since 01/12/16 under the accession numbers from KY171979 - KY171987 [3,4,15,19-21]. 
Table 1. Mean total non - hydrocarbon utilizing bacterial (TNHUB) count of sediment and water samples from the three sampled locations

\begin{tabular}{lll}
\hline Samples & Log CFU /g/ml & Percentage (\%) \\
\hline Abonema water & $13.60 \pm 0.02$ & $20.80 \pm 0.16$ \\
Abonema sediment & $12.70 \pm 0.02$ & $18.90 \pm 0.20$ \\
Nembe water & $18.95 \pm 0.04$ & $32.40 \pm 0.16$ \\
Nembe sediment & $11.50 \pm 0.04$ & $16.30 \pm 0.16$ \\
Onne water & $08.00 \pm 0.16$ & $08.70 \pm 0.20$ \\
Onne sediment & $05.34 \pm 0.02$ & $02.90 \pm 0.06$ \\
\hline
\end{tabular}

The values are mean \pm standard deviation of triplicate determination

Table 2. Mean total viable hydrocarbon utilizing bacterial (TVHUB) count of sediment and water samples from the three sampled locations

\begin{tabular}{|c|c|c|}
\hline Sample & Log CFU $/ \mathrm{g} / \mathrm{ml}$ & Percentage (\%) \\
\hline Abonema water + xylene & $04.35 \pm 0.04$ & $02.50 \pm 0.04$ \\
\hline Abonema sediment $+x y l e n e$ & $30.20 \pm 0.12$ & $17.30 \pm 0.12$ \\
\hline Abonema water + anthracene & $09.20 \pm 0.08$ & $05.30 \pm 0.08$ \\
\hline Abonema sediment + anthracene & $08.05 \pm 0.01$ & $04.60 \pm 0.02$ \\
\hline Abonema water + pyrene & $04.42 \pm 0.04$ & $02.50 \pm 0.04$ \\
\hline Abonema sediment + pyrene & $09.45 \pm 0.01$ & $05.40 \pm 0.02$ \\
\hline Nembe water + xylene & $12.35 \pm 0.02$ & $07.10 \pm 0.06$ \\
\hline Nembe sediment $+x y l e n e$ & $09.50 \pm 0.01$ & $05.50 \pm 0.01$ \\
\hline Nembe water + anthracene & $10.50 \pm 0.01$ & $06.00 \pm 0.12$ \\
\hline Nembe sediment + anthracene & $06.09 \pm 0.03$ & $03.50 \pm 0.02$ \\
\hline Nembe water + pyrene & $15.35 \pm 0.15$ & $08.80 \pm 0.02$ \\
\hline Nembe sediment + pyrene & $08.25 \pm 0.02$ & $04.70 \pm 0.02$ \\
\hline Onne water + xylene & $07.60 \pm 0.01$ & $04.40 \pm 0.02$ \\
\hline Onne sediment + xylene & $07.70 \pm 0.08$ & $04.40 \pm 0.08$ \\
\hline Onne water + anthracene & $05.20 \pm 0.02$ & $03.00 \pm 0.06$ \\
\hline Onne sediments + anthracene & $08.50 \pm 0.02$ & $04.90 \pm 0.01$ \\
\hline Onne water + pyrene & $10.50 \pm 0.02$ & $06.00 \pm 0.02$ \\
\hline Onne sediment + pyrene & $06.95 \pm 0.12$ & $04.00 \pm 0.12$ \\
\hline
\end{tabular}
The values are mean \pm standard deviation of triplicate determination

Table 3. Growth performance of the aromatic hydrocarbon - degraders isolated from Abonema sampled location

\begin{tabular}{|c|c|c|c|}
\hline \multirow[t]{2}{*}{ Isolate } & \multicolumn{2}{|c|}{ Optical density $\left(\mathrm{OD}_{600} \mathrm{~nm}\right)$} & \multirow[t]{2}{*}{ Pyrene } \\
\hline & Xylene & Anthracene & \\
\hline AB1 & $0.657 \pm 0.008$ & $0.657 \pm 0.001$ & $0.580 \pm 0.003$ \\
\hline ANT4* & $0.676 \pm 0.004$ & $0.775 \pm 0.007$ & $0.822 \pm 0.002$ \\
\hline AB3 & $0.701 \pm 0.021$ & $0.467 \pm 0.029$ & $0.666 \pm 0.003$ \\
\hline AB4 & $0.715 \pm 0.004$ & $0.598 \pm 0.024$ & $0.841 \pm 0.001$ \\
\hline PYR3* & $0.598 \pm 0.005$ & $0.511 \pm 0.003$ & $1.041 \pm 0.008$ \\
\hline AB6 & $0.641 \pm 0.001$ & $0.494 \pm 0.002$ & $0.653 \pm 0.001$ \\
\hline AB7 & $0.687 \pm 0.004$ & $0.690 \pm 0.002$ & $0.803 \pm 0.016$ \\
\hline AB8 & $0.618 \pm 0.001$ & $0.638 \pm 0.007$ & $0.782 \pm 0.003$ \\
\hline AB9 & $0.457 \pm 0.002$ & $0.475 \pm 0.001$ & $0.573 \pm 0.004$ \\
\hline XYL2* & $0.952 \pm 0.004$ & $0.312 \pm 0.002$ & $0.838 \pm 0.021$ \\
\hline AB11 & $0.793 \pm 0.014$ & $0.495 \pm 0.002$ & $0.970 \pm 0.003$ \\
\hline AB12 & $0.647 \pm 0.002$ & $0.446 \pm 0.001$ & $0.621 \pm 0.005$ \\
\hline AB13 & $0.328 \pm 0.001$ & $0.415 \pm 0.001$ & $0.451 \pm 0.001$ \\
\hline
\end{tabular}




\subsection{Detection of Catabolic and Surfactant Genes by PCR Analyses}

\subsubsection{PCR primer design}

Following the method of Swaathy et al. [19] as modified in this study, a portion of catechol gene $881 \mathrm{bp}(\mathrm{C23O})$ was pulled out from the genomic DNA using F: 5'- ATG AGC AAC AAA TAC GAA TT- 3 ' and R: 5'- TCA AAC GGT CAA TCT GAT AT- 3' (Fig. 6). Likewise, according to the method of Qazi et al. [21] and Swaathy et al. [3] as modified in this study, the primer pair of microsurf gene sifA3 /licA3 using $F$ : CAAAAKCGCAKCATATGAG and sifA3 /licA3 and R: AGCGGCAYATATTGATGCGGYTC was designed to amplify a 881 bp portion of the srfA3 or the homologous licA3 gene present in surfactin/lichenysin and gene - specific primers of rhamnolipid gene (rh/B) using kpd - F 5'GCCCACGACCAGTTCGAC-3' and kpd - R 5' CATCCCCCTCCCTATGAC-3') (Fig. 6). They were subjected to the same PCR and gel electrophoretic conditions and protocols stated above [18].

\subsection{Data Analysis}

All values were expressed as mean \pm S.D. and ordinary one-way analysis of variance (ANOVA) followed by post Tukey's, multiple comparison test was performed on the data obtained using Graph-Pad Prism version 7.00. The results were considered statistically significant at $95 \%$ confidence intervals $(P=.05)[15,16]$.

\section{RESULTS}

\subsection{Bacterial Enumeration}

The result of the mean total non-hydrocarbon utilizing bacterial (TNHUB) count of sediment and water samples from the three sampled locations is presented on Table 1. From the result, Nembe water had the highest significant $(P=.05)$ mean TNHUB count of $\log 18.95 \pm 0.04$ CFU / $\mathrm{mL}$ with highest percentage of occurrence $(32.40 \pm 0.16 \%)$ while Onne sediment had the lowest significant $(P=.05)$ mean TNHUB count of $\log 05.34 \pm 0.02 \mathrm{CFU} / g$ with lowest percentage of occurrence (02.90 $\pm 0.06 \%)$ respectively. Similarly, the result of the mean total viable hydrocarbon utilizing bacterial (TVHUB) count sediment and water samples from the three sampled locations is presented on Table 2. From the result, Abonema sediment with xylene and
Abonema water with xylene had the highest significant $(P=.05)$ mean TVHUB count of log $30.20 \pm 0.12 \mathrm{CFU} / \mathrm{g}$ with highest percentage of occurrence $(17.30 \pm 0.12 \%)$ and the lowest significant $(P=.05)$ mean TVHUB count of log $04.35 \pm 0.04 \mathrm{CFU} / \mathrm{mL}$ with lowest percentage of occurrence $(02.50 \pm 0.04 \%)$ respectively.

\subsection{Degradability Test}

The result of the growth performance $\left(\mathrm{OD}_{600} \mathrm{~nm}\right)$ of the aromatic hydrocarbon - degraders isolated from Abonema sampled location is presented in Table 3. From the result, 13 isolates were obtained with strains XYL2, ANT4 and PYR3 having the highest significant $(P=.05)$ absorbance values of $0.952 \pm 0.004,0.775 \pm$ 0.007 and $1.041 \pm 0.008$ on xylene, anthracene and pyrene hydrocarbons. The result of the growth performance $\left(\mathrm{OD}_{600} \mathrm{~nm}\right)$ of the aromatic hydrocarbon - degraders isolated from Nembe sampled location is presented in Table 4. From the result, 17 isolates were obtained with strains XYL7, ANT1 and PYR5 having the highest significant $(P=.05)$ absorbance values of 1.055 $\pm 0.002,0.816 \pm 0.007$ and $0.933 \pm 0.007$ on xylene, anthracene and pyrene hydrocarbons. The result of the growth performance $\left(\mathrm{OD}_{600} \mathrm{~nm}\right)$ of the aromatic hydrocarbon - degraders isolated from Onne sampled location is presented in Table 5. From the result, 18 isolates were obtained with strains XYL8, ANT6 and PYR9 having the highest significant $(P=.05)$ absorbance values of $0.741 \pm 0.007,1.433 \pm$ 0.013 and $0.871 \pm 0.001$ on xylene, anthracene and pyrene hydrocarbons. On the basis of these results, strains ANT1, XYL2, PYR3, ANT4, PYR5, ANT6, XYL7, XYL8 and PYR9 were selected as the best and strongest degraders of xylene, anthracene and pyrene hydrocarbons.

\subsection{Molecular Characterization of Bacterial Isolates}

The result of the PCR - amplification of $16 S$ rRNA genes of the aromatic degrading bacteria genomic DNA is shown in Fig. 4. From the result, it was confirmed that the PCR products obtained using universal primer $16 \mathrm{~S}-\mathrm{P} 1 \mathrm{PCR}\left(27 \mathrm{~F} 5^{\prime}-\right.$ : AGA GTT TGA TCC TGG CTC AG - 3') and 16S - P2 PCR (1492 R 5' - ACG GCT ACC TTG TTA CGA CTT - 3') have the molecular weight of 1 $\mathrm{kbp}$ visualized by UV fluorescence under agarose gel electrophoresis. The result of the percentage similarity and GenBank accession numbers of $16 \mathrm{~S}$ rRNA sequences of the closest relative for the aromatic degrading bacterial 
isolates is presented in Table 6. From the result, Alcaligenes faecalis was the most blasted bacteria with high similarity (98 - 99\%) followed by Providencia spp. (95 - 97\%), Brevundimonas diminuta (100\%), Myroides odoratus (90\%), Serratia marcescens (97\%) and Bacillus cereus (98\%) using NCBI BLAST software. The result of neighbour - joining phylogenetic relationship among the 16S rRNA sequence of the aromatic degrading bacterial isolates constructed by MEGA 7.0 is shown in Fig. 5. From the result, it revealed that the nine bacterial isolates (KY171979, KY171984, KY171987, KY171980, KY171982, KY171981, KY171985, KY171986 and $K Y 171983)$ arise from similar clusters and node establishing that they are correlationally connected to one another with common origin.

\subsection{Detection of Catabolic and Surfactant Genes}

The result of the catabolic and surfactant genes detected in some of the marine aromatic degrading bacterial isolates using specific primers for each gene is presented in Table 7 while the result of the PCR - amplification of primers specific for catabolic gene $(C 230)$ and surfactant genes (rh/B, SrfA3 /LicA3) of Providencia vermicola strain ANT1, Alcaligenes faecalis strain XYL2, Serratia marcescens strain XYL7 and Providencia sp. strain XYL8 is shown in Fig. 6. From the results, catabolic gene
(C23O) was detected in only four (4) out of the nine marine aromatic degrading bacteria with name stated above while surfactant genes ( $r h / B$, SrfA3 /LicA3) were detected only in three (3) out of the nine marine aromatic degrading bacteria all of which had 881 base pairs sizes of PCR products of the catabolic and surfactant genes visualized by UV fluorescence under agarose gel electrophoresis respectively.

\section{DISCUSSION}

In this study, an attempt was made to explore the diversity, catabolic and surfactant genes of marine hydrocarbon utilizing bacteria from our three study areas and the result in Tables 1 and 2 showed that surface water harbours more non - hydrocarbon utilizing bacteria which could possibly be due to the more nutrient and oxygen levels in surface water than the sediment samples. The result in Table 2 showed that sediment surface harbours more hydrocarbon utilizing bacteria than surface water possibly due to the high accumulative nature of sediment to aromatic compounds than water. Aromatic compounds tend to have low solubility to water hence making them adsorbed more to sediment than surface water. Comparatively, there was significant abundance of NHUB more than HUB and more xylene degraders than anthracene and pyrene degraders in the both samples respectively. The result uphold the findings of

Table 4. Growth performance of the aromatic hydrocarbon - degraders isolated from Nembe sampled location

\begin{tabular}{|c|c|c|c|}
\hline \multirow[t]{2}{*}{ Isolate } & \multicolumn{2}{|c|}{ Optical density $\left(\mathrm{OD}_{600} \mathrm{~nm}\right)$} & \multirow[t]{2}{*}{ Pyrene } \\
\hline & Xylene & Anthracene & \\
\hline NW1 & $0.885 \pm 0.003$ & $0.236 \pm 0.005$ & $0.708 \pm 0.008$ \\
\hline PYR5* & $0.710 \pm 0.003$ & $0.216 \pm 0.005$ & $0.933 \pm 0.007$ \\
\hline NW3 & $0.466 \pm 0.007$ & $0.201 \pm 0.000$ & $0.806 \pm 0.004$ \\
\hline NW4 & $0.893 \pm 0.002$ & $0.356 \pm 0.008$ & $0.827 \pm 0.008$ \\
\hline NW5 & $0.750 \pm 0.004$ & $0.132 \pm 0.005$ & $0.767 \pm 0.008$ \\
\hline NW6 & $0.644 \pm 0.004$ & $0.246 \pm 0.004$ & $0.724 \pm 0.008$ \\
\hline NW7 & $0.561 \pm 0.003$ & $0.193 \pm 0.005$ & $0.808 \pm 0.001$ \\
\hline NW8 & $0.628 \pm 0.008$ & $0.472 \pm 0.001$ & $0.826 \pm 0.008$ \\
\hline$X Y L 7 *$ & $1.055 \pm 0.002$ & $0.588 \pm 0.005$ & $0.927 \pm 0.001$ \\
\hline NW10 & $0.809 \pm 0.002$ & $0.785 \pm 0.002$ & $0.881 \pm 0.004$ \\
\hline NW11 & $0.826 \pm 0.001$ & $0.444 \pm 0.002$ & $0.891 \pm 0.001$ \\
\hline NW12 & $0.625 \pm 0.005$ & $0.563 \pm 0.001$ & $0.728 \pm 0.006$ \\
\hline NW13 & $0.374 \pm 0.008$ & $0.775 \pm 0.001$ & $0.760 \pm 0.001$ \\
\hline NW14 & $0.701 \pm 0.001$ & $0.622 \pm 0.003$ & $0.788 \pm 0.007$ \\
\hline NW15 & $0.705 \pm 0.008$ & $0.529 \pm 0.004$ & $0.830 \pm 0.002$ \\
\hline NW16 & $0.769 \pm 0.002$ & $0.380 \pm 0.001$ & $0.822 \pm 0.001$ \\
\hline ANT1* & $0.804 \pm 0.003$ & $0.816 \pm 0.007$ & $0.583 \pm 0.001$ \\
\hline
\end{tabular}


Table 5. Growth performance of the aromatic hydrocarbon - degraders isolated from Onne sampled location

\begin{tabular}{llll}
\hline Isolate & \multicolumn{2}{c}{ Optical density $\left(\mathbf{O D}_{\mathbf{6 0 0}} \mathbf{n m}\right)$} & \multirow{2}{*}{ Pyrene } \\
\cline { 2 - 3 } & Xylene & Anthracene & \\
\hline ON1 & $0.721 \pm 0.001$ & $0.884 \pm 0.007$ & $0.500 \pm 0.001$ \\
ON2 & $0.204 \pm 0.001$ & $0.660 \pm 0.011$ & $0.454 \pm 0.001$ \\
ON3 & $0.473 \pm 0.003$ & $0.476 \pm 0.036$ & $0.561 \pm 0.013$ \\
ON4 & $0.207 \pm 0.001$ & $0.766 \pm 0.001$ & $0.565 \pm 0.033$ \\
ON5 & $0.477 \pm 0.002$ & $0.457 \pm 0.001$ & $0.378 \pm 0.005$ \\
ON6 & $0.409 \pm 0.005$ & $0.489 \pm 0.100$ & $0.562 \pm 0.021$ \\
ON7 & $0.251 \pm 0.003$ & $0.428 \pm 0.014$ & $0.728 \pm 0.001$ \\
ON8 & $0.111 \pm 0.005$ & $0.429 \pm 0.014$ & $0.425 \pm 0.021$ \\
ON9 & $0.463 \pm 0.008$ & $0.357 \pm 0.011$ & $0.281 \pm 0.006$ \\
PYR9* & $0.106 \pm 0.001$ & $0.335 \pm 0.001$ & $0.871 \pm 0.001$ \\
ON11 & $0.700 \pm 0.001$ & $0.901 \pm 0.005$ & $0.417 \pm 0.002$ \\
ANT6* & $0.511 \pm 0.006$ & $1.433 \pm 0.013$ & $0.568 \pm 0.009$ \\
ON13 & $0.273 \pm 0.002$ & $0.386 \pm 0.002$ & $0.527 \pm 0.001$ \\
ON14 & $0.278 \pm 0.005$ & $0.553 \pm 0.022$ & $0.684 \pm 0.003$ \\
ON15 & $0.291 \pm 0.003$ & $0.748 \pm 0.009$ & $0.522 \pm 0.010$ \\
ON16 & $0.662 \pm 0.001$ & $0.919 \pm 0.002$ & $0.494 \pm 0.002$ \\
XYL8* & $0.741 \pm 0.007$ & $0.510 \pm 0.013$ & $0.602 \pm 0.004$ \\
ON18 & $0.354 \pm 0.002$ & $1.004 \pm 0.001$ & $0.478 \pm 0.001$ \\
\hline${ }^{*}=$ Isolates with highest degradability; values are mean \pm standard deviation of triplicate determination
\end{tabular}

Table 6. Percentage similarity and GenBank accession numbers of 16S rRNA sequences of the closest relative for the aromatic degrading bacterial isolates

\begin{tabular}{llllllll}
\hline $\begin{array}{l}\text { Isolate } \\
\text { code }\end{array}$ & $\begin{array}{l}\text { Closest relative in } \\
\text { GenBank }\end{array}$ & $\begin{array}{l}\text { Max } \\
\text { score }\end{array}$ & $\begin{array}{l}\text { Total } \\
\text { score }\end{array}$ & $\begin{array}{l}\text { Query } \\
\text { coverage }\end{array}$ & $\begin{array}{l}\text { E. } \\
\text { value }\end{array}$ & $\begin{array}{l}\text { Max } \\
\text { identity }\end{array}$ & $\begin{array}{l}\text { Accession } \\
\text { number }\end{array}$ \\
\hline ANT1 & $\begin{array}{l}\text { Providencia vermicola } \\
\text { strain MTCC 5578 }\end{array}$ & 544 & 544 & $93 \%$ & $6 \mathrm{e}-151$ & $95 \%$ & $\mathrm{KY} 171979$ \\
XYL2 & $\begin{array}{l}\text { Alcaligenes faecalis } \\
\text { strain MOR02 }\end{array}$ & 1559 & 4679 & $99 \%$ & 0.0 & $99 \%$ & $\mathrm{KY} 171984$ \\
PYR3 & $\begin{array}{l}\text { Brevundimonas } \\
\text { diminuta strain zjs01 }\end{array}$ & 1489 & 1489 & $97 \%$ & 0.0 & $100 \%$ & $\mathrm{KY} 171987$ \\
ANT4 & $\begin{array}{l}\text { Alcaligenes faecalis } \\
\text { strain MOR02 }\end{array}$ & 1594 & 1594 & $99 \%$ & 0.0 & $99 \%$ & $\mathrm{KY} 171980$ \\
PYR5 & $\begin{array}{l}\text { Alcaligenes faecalis } \\
\text { strain MOR02 }\end{array}$ & 1537 & 4612 & $98 \%$ & 0.0 & $98 \%$ & $\mathrm{KY} 171982$ \\
ANT6 & $\begin{array}{l}\text { Myroides odoratus } \\
\text { strain D25T }\end{array}$ & 1194 & 1194 & $95 \%$ & 0.0 & $90 \%$ & $\mathrm{KY} 171981$ \\
XYL7 & $\begin{array}{l}\text { Serratia marcescens } \\
\text { strain SM6 }\end{array}$ & 1476 & 1476 & $98 \%$ & 0.0 & $97 \%$ & $\mathrm{KY} 171985$ \\
XYL8 & $\begin{array}{l}\text { Providencia sp. strain } \\
\text { X1 }\end{array}$ & 1491 & 1491 & $98 \%$ & 0.0 & $97 \%$ & $\mathrm{KY} 171986$ \\
PYR9 & $\begin{array}{l}\text { Bacillus cereus strain } \\
\text { B4 }\end{array}$ & 1543 & 16940 & $98 \%$ & 0.0 & $98 \%$ & $\mathrm{KY} 171983$ \\
\hline
\end{tabular}

Chikere et al. [7] who reported that these of hydrocarbons. Additional factor that decreases waterways are unceasingly open to petroleum existing metabolic nutrients in marine ecosystem hydrocarbons due to navigational actions and this according to $\mathrm{Xu}$ et al. [22], is substantial possibly will have augmented the sediment with percolation initiated by tidal flood and wave hydrocarbon utilizing bacteria. However, the action. The existence of hydrocarbon utilizers in insufficiency of the HUB counts could be ascribed the midst of the heterotrophic population in the to the lack of nutrients at that depth especially samples is a sign of earlier contamination owing nitrogen and phosphorus which reduce with input to hydrocarbon pollution [12,23]. 
Table 7. Catabolic and surfactant genes detected in some of the marine aromatic degrading bacterial isolates using specific primers for each gene

\begin{tabular}{llllll}
\hline Isolate code & Bacterial name & Expected band (bp) & C230 & rhIB & SrfA3 /LicA3 \\
\hline ANT1 & Providencia vermicola & $881 \mathrm{bp}$ & + & - & - \\
XYL2 & Alcaligenes faecalis & $881 \mathrm{bp}$ & + & + & - \\
PYR3 & Brevundimonas diminuta & - & - & - & - \\
ANT4 & Alcaligenes faecalis & - & - & - & - \\
PYR5 & Alcaligenes faecalis & - & - & - & - \\
ANT6 & Myroides odoratus & - & - & - & - \\
XYL7 & Serratia marcescens & $881 \mathrm{bp}$ & + & + & + \\
XYL8 & Providencia sp. & $881 \mathrm{bp}$ & + & + & + \\
PYR9 & Bacillus cereus & - & - & - & - \\
\multicolumn{5}{r}{} \\
\hline
\end{tabular}

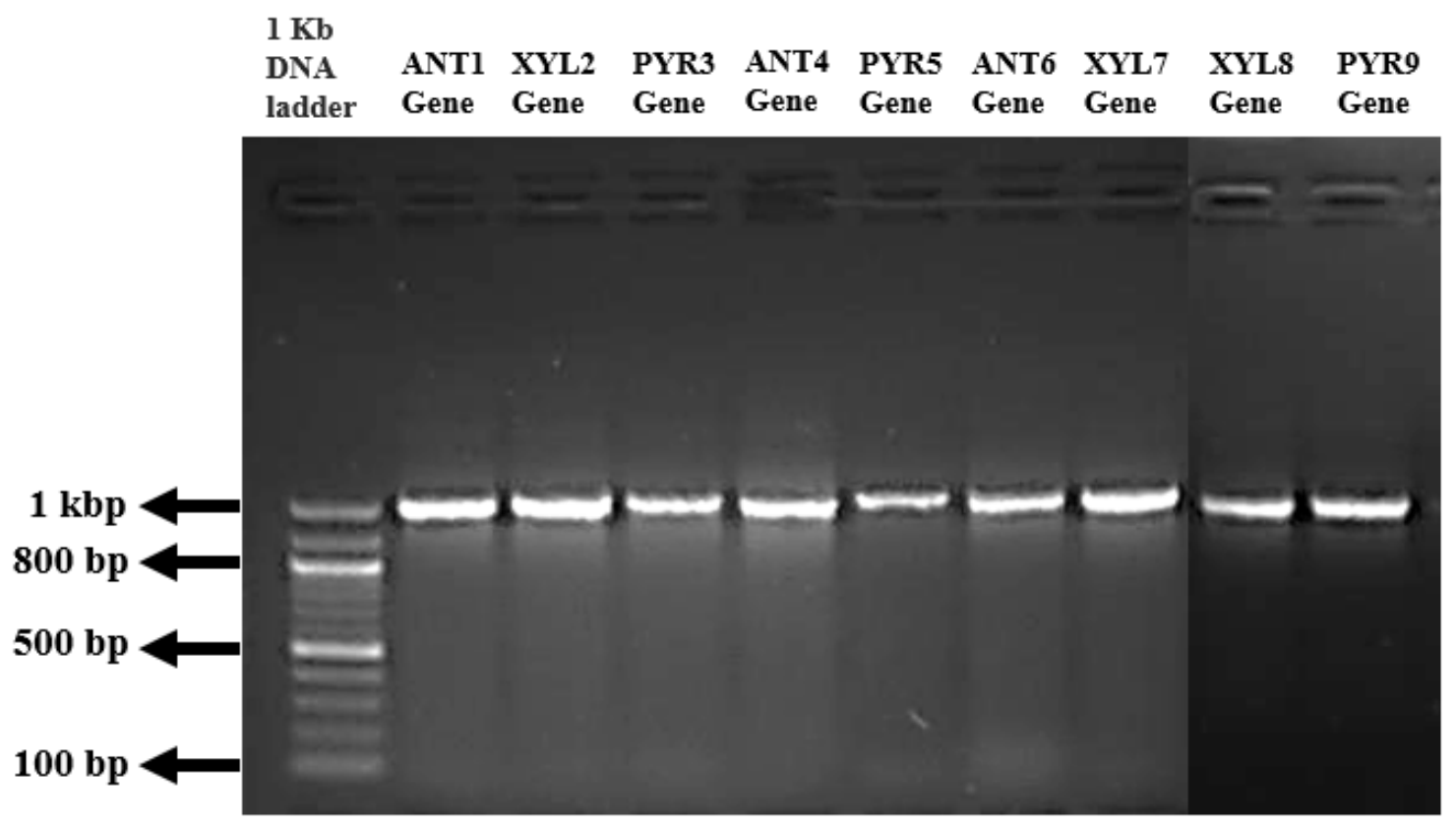

Fig. 4. PCR - amplification of $16 \mathrm{~S}$ rRNA genes of the aromatic degrading bacteria genomic DNA

Following isolation, a total of nine (9) isolates ANT1, XYL2, PYR3, ANT4, PYR5, ANT6, XYL7, XYL8 and PYR9 out of the 48 isolates (9/48) representing $18.75 \%$ of the isolates were screened and selected as best and strongest degraders of xylene, anthracene and pyrene hydrocarbons which they significantly $(P=.05)$ utilize as source of carbon and energy and are indicated by absorbance values of each isolates (Tables 3, 4 and 5). The result is justified by the finding of Mao et al. [24], who reported that the enrichment and isolation of native $\mathrm{PAH}$ degraders is the most essential feature of microbial degradation of $\mathrm{PAH}$ as the native $\mathrm{PAH}$ degraders possess the adaptive traits to these hydrocarbons. Pathak and Bhatnagar [25], reported that enrichment culturing is very imperative towards the attainment of hydrocarbon bioremediation as it leads to selection of microbial degraders that are better adapted to hydrocarbons. Esedafe et al. [12] reported that an occurrence of 3/41 representing $7.32 \%$ isolates from refinery effluent were efficient in degrading the polyaromatic hydrocarbons (PAHs).

The result in Fig. 4 confirmed that the PCR products of the genomic DNA of the isolated bacteria had the molecular weight of $1 \mathrm{kbp}$. Akinbankole et al. [26], obtained 1,500 bp PCR product from anthracene and pyrene degrading bacteria isolated from petroleum polluted water 


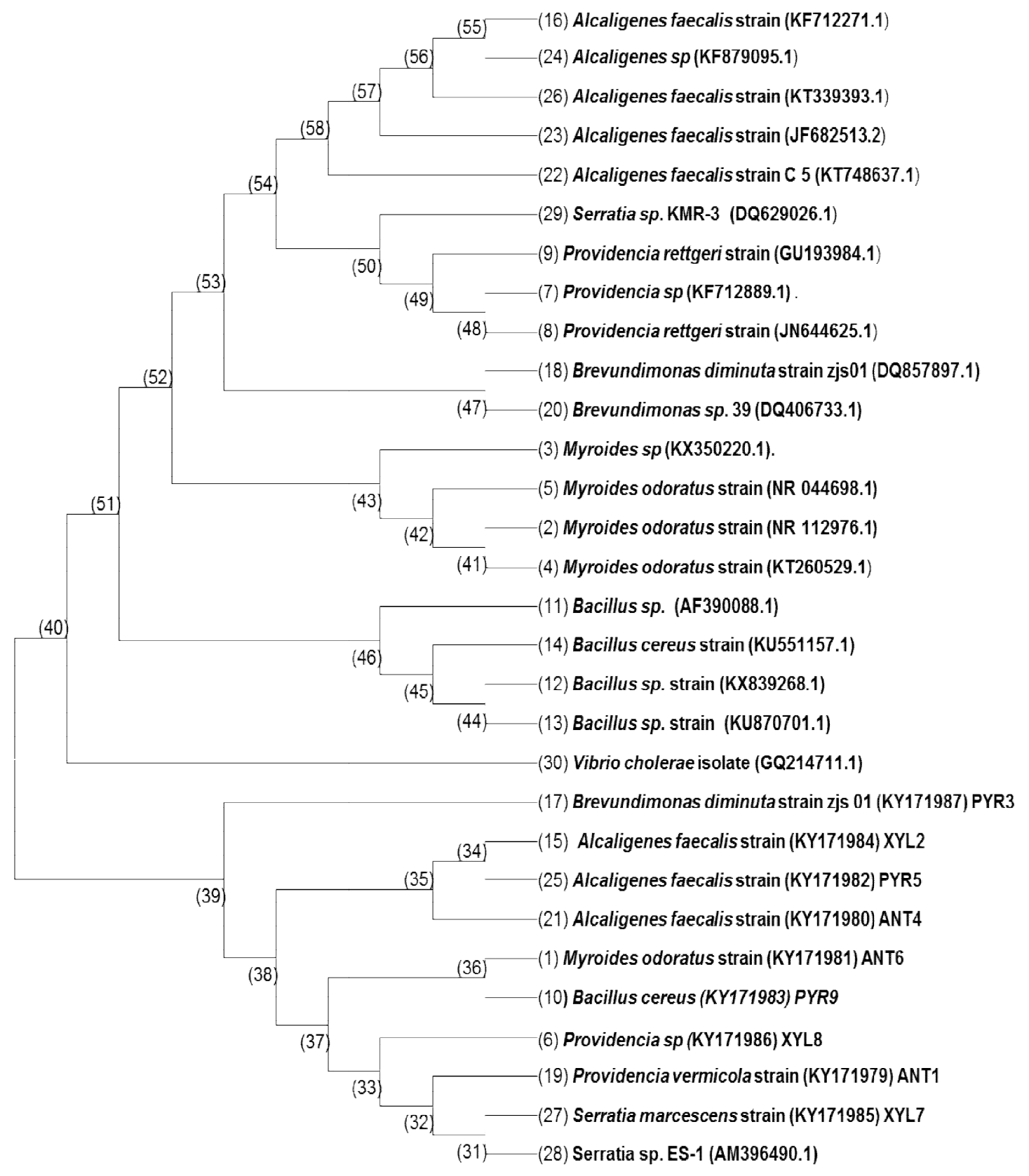

Fig. 5. Neighbour - joining phylogenetic relationship among the 16S rRNA sequence of the aromatic degrading bacterial isolates constructed by MEGA 7.0

Numbers at the nodes indicate bootstrap support (\%) based on 1000 replicates. The sum of branch length = 0.93646865 using $p$ - distance method involving 9 nucleotide sequences with total of 303 positions. GenBank accession numbers are given in parentheses

and soil in Malaysia in their research finding. Yuliani et al. [17], obtained in their research 1,489 bp PCR product from phenanthrene and pyrene degrading bacteria isolated from marine region of Indonesia. Isiodu et al. [15], reported that all the seven (7) polyaromatic hydrocarbon utilizing bacterial isolates isolated from Bodo Creek brackish water in Nigeria showed amplification with an amplicon size of $500 \mathrm{bp}$. The result in Table 6 showed that Alcaligenes faecalis was the most occurring organism after blasting with high sequence similarity (98-99\%) 


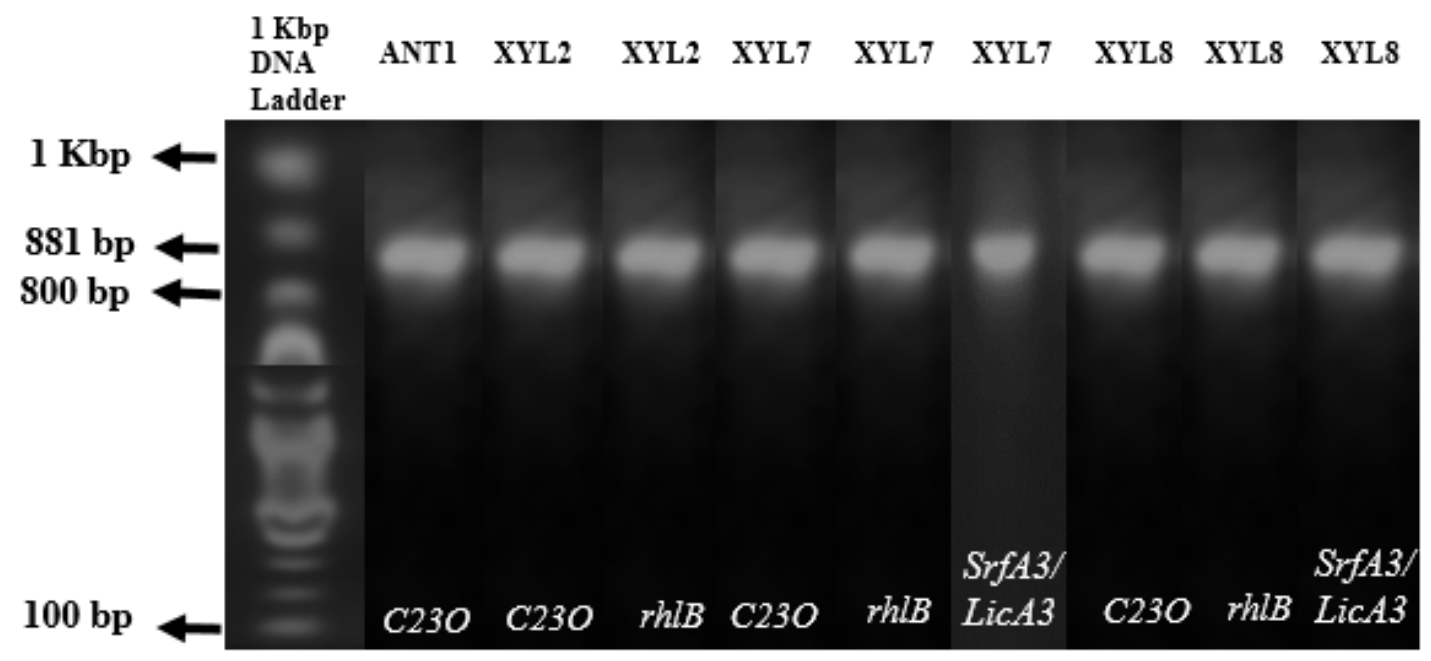

Fig. 6. PCR - amplification of primers specific for catabolic gene (C23O) and surfactant genes (rhIB, SrfA3 /LicA3) of Providencia vermicola strain ANT1, Alcaligenes faecalis strain XYL2, Serratia marcescens strain XYL7 and Providencia sp. strain XYL8

followed by Providencia spp. (95 - 97\%), Brevundimonas diminuta (100\%), Myroides odoratus (90\%), Serratia marcescens (97\%) and Bacillus cereus (98\%) using NCBI BLAST software. Akinbankole et al. [26], found out that $B$. cereus was the most blasted organism with $99 \%$ sequence similarity. The phylogenetic tree showed the evolutionary correlation among hydrocarbon metabolizing bacteria isolated in this study. The result shown in Fig. 5 revealed that the nine bacterial isolates (KY171979, KY171984, KY171987, KY171980, KY171982, KY171981, KY171985, KY171986 and KY171983) had similar lineage as they arise from analogous node and hence they are evolutionary connected to their relatives in the GenBank. The sequences of these genes have been submitted to NCBI/GenBank database since first of December two thousand and sixteen (01/12/16). They belong to the genera: Providencia, Alcaligenes, Brevundimonas, Myroides, Serratia, and Bacillus; and families of: Enterobacteriaceae, Alcaliginaceae, Caulobacteriaceae, Flavobacteriaceae, and Bacillaceae; and phyla of: Proteobacteria, Bacteroidetes and Firmicutes which members have been implicated in petroleum and aromatic hydrocarbon biodegradation by several authors $[7,10,15,17,19,26-33]$.

In order to broaden the description of the aromatic hydrocarbon - degrading bacteria isolated from the Rivers marine environment, PCR assays were performed to explore for functional genes coding for the catechol 2, 3 dioxygenase enzyme (C23O) and genes related to surfactant production namely rhamnolipid enzyme $(r h / B)$ and surfactin/lichenysin enzyme (SrfA3 /LicA3) and the results are presented and shown in Table 7 and Fig. 6. From the results, catabolic gene (C230) was detected in only four (4) out of the nine marine aromatic degrading bacteria with name stated above while surfactant genes ( $r h / B$, SrfA3 /LicA3) were detected only in three (3) out of the nine marine aromatic degrading bacteria all of which had 881 base pairs sizes of PCR products of the catabolic and surfactant genes. Even though biosurfactants aid in solubilizing or mediating the interface between the bacterial degraders and the aromatic compounds, the catabolic responses detected in our study were effected by the dioxygenase genes as revealed from the amplified products of 881 bps. The detection of C230 gene in some of the Gram negative bacteria and not in the Gram positive bacteria showed that these strains (ANT1, XYL2, XYL7 and XYL8) synthesize dioxygenases for either complete or partial breakdown of aromatic hydrocarbons (xylene, anthracene and pyrene) and a probable reason could be that the detected genes were highly preserved among diverse Gram - negative bacteria; hence support the research work of Hesham et al. [4], who confirmed the existence of both monooxygenase and dioxygenase in $S$. koreensis strain ASU - 06. C12O and C230 dioxygenases have been known to contribute a significant part in the catabolism of aromatic 
rings by the bacteria as they are responsible for splitting of aromatic $\mathrm{C}-\mathrm{C}$ bond at ortho or meta positions. The implication of the gene $\mathrm{C} 23 \mathrm{O}$ as an essential gene in the catabolism of low and high molecular weights PAHs has been reported by Swaathy et al. [19]. Moreso, the detection of rhamnolipid $(r h / B)$ and surfactin /lichenysin (SrfA3 /LicA3) genes in these strains support the continuous argument among the scientists about the occurrence of $r h / B$ and SrfA3 /LicA3 genes in bacteria other than Pseudomonas and Bacillus species and several new strains of bacteria having exceptional ability to synthesize rhamnolipids have in recent times been described. There are dearth of reports documented on rhamnolipid production among pathogens especially Burkholderia mallei and $B$. pseudomallei and the non - pathogenic especially $B$. thailandensis. This observation contradicts the findings of Swaathy et al. $[3,19]$, who found out that the expression of sif and licA3 genes were only realized in all of the five Bacillus species and marine Bacillus licheniformis MTCC 5514. On the other hand, those isolates that could grow on the aromatic hydrocarbons but had unsuccessful amplification, could be as a result of incompatibilities among the tested primers and gene sequences [34] and may contain other catabolic and surfactant genes aside the tested genes.

\section{CONCLUSION}

The whole study revealed that the three sampling sites harbour a lot of phylogenetically related aromatic hydrocarbon degrading bacterial strains belonging to the genera: Providencia, Alcaligenes, Brevundimonas, Myroides, Serratia, and Bacillus which are able to utilize xylene, anthracene and pyrene as source of carbon and energy. It also revealed that some of the isolated bacteria especially Serratia marcescens XYL7 possess functional genes coding for aromatic degradation and surfactant production. Our results suggest that these bacteria may possibly play a significant part in degradation of simple, low and high molecular weight aromatic hydrocarbons and could be recommended for in situ aromatic hydrocarbon bioremediation in the Niger Delta environment.

\section{ACKNOWLEDGEMENTS}

The research work described in this paper was supported by fund from the year 2012/2013 (Merged) Tertiary Education Trust Fund (TETFUND) Academic Staff Training and
Development of Chukwuemeka Odumegwu Ojukwu Universit, Uli Campus. Also, I want to thank in a special way Prof. (Dame) E. I. Chukwura who supervise the work and Mr Ubani, Onyedika of Department of Environmental Sciences, University of South Africa, Pretoria, South Africa for his technical assistance towards completion of the work. The anonymous reviewers are sincerely thanked for their beneficial suggestions to improve the manuscript.

\section{COMPETING INTERESTS}

Author has declared that no competing interests exist.

\section{REFERENCES}

1. Nwilo PC, Badejo OT. Oil spill problems and the management in the Niger Delta. International Oil Spill Conference, Miami, Florida, USA. 2005;20-2.

2. Rajaei S, Seyedi SM, Raiesi F, Shiran B, Raheb J. Characterization and potentials of oil-degrading bacteria inhabiting the rhizosphere of wild oat (Avena fatua L.) in South West of Iran. Iran J Biotech. 2013; 11(1):32- 40.

3. Swaathy S, Kavitha V, Pravin AS, Sekaran G, Mandal AB, Gnanamani A. (2014a). Phylogenetic framework and biosurfactant gene expression analysis of marine Bacillus spp. of Eastern Coastal Plain of Tamil Nadu. Internat J Bact. 2014a; 860491.

4. Hesham AE, Mawad AMM, Mostafa YM, Shoreit A. Biodegradation ability and catabolic genes of petroleum-degrading Sphingomonas koreensis strain ASU-06 isolated from Egyptian oily soil. BioMed Res Internat. 2014;127674.

5. Nakamura FM, Germano MG, Tsai SM. Capacity of aromatic compound degradation by bacteria from Amazon Dark Earth. Diver. 2014;6:339-53.

6. Ma J, Xu L, Jia L. Degradation of polycyclic aromatic hydrocarbons by Pseudomonas sp. JM2 isolated from active sewage sludge of chemical plant. J Environ Sci. 2012;24(12):2141-8.

7. Chikere CB, Okpokwasili GC, Ichiakor O. Characterization of hydrocarbon utilizing bacteria in tropical marine sediments. Afr $\mathrm{J}$ Biotech. 2009;8(11):2541-44.

8. Abu GO, Chikere BO. Cell surface properties of hydrocarbon utilizing bacterial 
isolates from the Port Harcourt marine environment. Nig J Microbiol. 2006;20(1): 809-16.

9. Gorleku MA, Carboo D, Palm LMN, Quasie WJ, Armah AK. Polycyclic aromatic hydrocarbons (PAHs) pollution in marine waters and sediments at the Tema Harbour, Ghana. Acad J Environ Sci. 2014;2(7):108-15.

10. John RC, Essien JP, Akpan SB, Okpokwasili GC. Polycyclic aromatic hydrocarbon degrading bacteria from aviation fuel spill site at Ibeno, Nigeria. Bull Environ Contam Toxicol. 2012;88:1014-9.

11. John RC, Okpokwasili GC. Crude oildegradation and plasmid profile of nitrifying bacteria isolated from oil impacted mangrove sediment in the Niger Delta of Nigeria. Bull Environ Contam Toxicol. 2012;88:1020-6.

12. Esedafe WK, Fagade OE, Umaru FF, Akinwotu $\mathrm{O}$. Bacterial degradation of the polycyclic aromatic hydrocarbon (PAH) fraction of refinery effluent. Internat $J$ Environ Biorem Biodeg. 2015;3(1):23-7.

13. Bahig AE, Aly EA, Khaled AA, and Amel KA. Isolation, characterization and application of bacterial population from agricultural soil at Sohag Province, Egypt. Mal J Microbiol. 2008;4(2):42-50.

14. Kafilzadeh F, Pour FH, Tahery Y, Azad $\mathrm{HN}$. Bioremediation of pyrene by isolated bacterial strains from the soil of the landfills in Shiraz (Iran). Ann Biol Res. 2012;3(1): 486-94.

15. Isiodu GG, Stanley HO, Ezebuiro V, Okerentugba PO. Role of plasmid-borne genes in the biodegradation of polycyclic aromatic hydrocarbons (PAHs) by consortium of aerobic heterotrophic bacteria. J Petr Environ Biotech. 2016;7(1): 264.

16. Kafilzadeh F, Pour FH. Degradation of naphthalene, phenanthrene and pyrene by Pseudomonas sp. and Corynebacterium sp. in the landfills. Internat J Biosci. 2012; 2(9):77-84.

17. Yuliani $H$, Sahlan $M$, Hermansyah $H$, Wijanarko A. Selection and identification of polyaromatic hydrocarbon degrading bacteria. World Appl Sci J. 2012;20(8): 1133-8.

18. Ubani O, Atagana $\mathrm{HI}$, Thantsha MS, Rasheed A. Identification and characterisation of oil sludge degrading bacteria isolated from compost. Arch Environ Prot. 2016;42(2):67-77.
19. Swaathy S, Kavitha V, Pravin AS, Mandal, $A B$, Gnanamani A. Microbial surfactant mediated degradation of anthracene in aqueous phase by marine Bacillus licheniformis MTCC 5514. Biotech Rep. 2014b;4:161-70.

20. Guo C, Dang Z, Wong Y, Tam NF. Biodegradation ability and dioxgenase genes of PAH-degrading Sphingomonas and Mycobacterium strains isolated from mangrove sediments. Internat Biodet Biodeg. 2010;64:419-26.

21. Qazi MA, Malik ZA, Qureshi GD, Hameed A, Ahmed S. Yeast extract as the most preferable substrate for optimized biosurfactant production by rh/B gene positive Pseudomonas putida SOL-10 isolate. J Biorem Biodeg. 2013;4(7):204.

22. $\mathrm{Xu} \mathrm{R}$, Lau NLA, Ng KL, Obbard JP Application of a slow-release fertilizer for oil bioremediation in beach sediments. J Environ Qual. 2004;33:1210-6.

23. Al-Thani RF, Abd-El-Haleem DAM, AlShammri M. Isolation and characterization of polyaromatic hydrocarbons-degrading bacteria from different Qatari soils. Afr. J. Microbiol. Res. 2009;3(11):761-6.

24. Mao J, Luo Y, Teng Y, Li Z. Bioremediation of polycyclic aromatic hydrocarboncontaminated soil by a bacterial consortium and associated microbial community changes. Internat Biodet Biodeg. 2012;70:141-7.

25. Pathak H, Bhatnagar K. Alcaligenes-the 4T engine oil degrader. J Biorem and Biodeg. 2011;2(4):2-5.

26. Akinbankole AS, Tunung R, Tennant AM. Biochemical and molecular characterization of pyrene and anthracene metabolizing bacteria isolated from oil contaminated water and soil in Malaysia. J Appl Environ Microbiol. 2015;3(1):25-30.

27. Amer RA, Mapelli F, El-Gendi HM, Barbato M, Goda DA, Corsini A, Cavalca L, Fusi M, Borin S, Daffonchio D, Abdel-Fattah YR. Bacterial diversity and bioremediation potential of the highly contaminated marine sediments at El-Max District (Egypt, Mediterranean Sea). Biomed Res Internat 2015;2015:981-9.

28. Fagbemi OK, Sanusi Al. Chromosomal and plasmid mediated degradation of crude oil by Bacillus coagulans, Citrobacter koseri and Serratia ficaria isolated from the soil. Afr J Biotech. 2017;16(21):1242-53.

29. Athar MA, Akbar A, Khan YH, Ali I, Mehmood U, Sabri AN, Hasnain $S$. 
Characterization of hydrocarbon degrading bacteria isolated from hydrocarbon contaminated soil. J Pure Appl Microbiol. 2014;8(6):1-9.

30. Ichor T, Okerentugba PO, Okpokwasili GC. Biodegradation of total petroleum hydrocarbon by aerobic heterotrophic bacteria isolated from crude oil contaminated brackish waters of Bodo Creek. J Biorem Biodeg. 2014;5(5):236-41.

31. Irshaid $\mathrm{FI}$, Jacob JH. Screening and characterization of aerobic xylenedegrading bacteria from gasoline contaminated soil sites around gas stations in Northern Jordan. J Biol Sci. 2015;15(4): 167-76.

32. Louvado A, Gomes NCM, Simões MMQ, Almeida A, Cleary DFR, Cunha A.
Polycyclic aromatic hydrocarbons in deep sea sediments: Microbe-pollutant interactions in a remote environment. Sci Tot Environ. 2015;526:312-28.

33. Patowary K, Saikia RR, Kalita MC, Deka S. Degradation of polyaromatic hydrocarbons employing biosurfactant-producing Bacillus pumilus KSs2. Ann Microbiol. 2015;65: 225-34.

34. Ding GC, Heuer H, Zühlke S, Spiteller M, Pronk GJ, Heister $\mathrm{K}$ et al. Soil typedependent responses to phenanthrene as revealed by determining the diversity and abundance of polycyclic aromatic hydrocarbon ring - hydroxylating dioxygenase genes by using a novel PCR detection system. Appl Environ Microbiol. 2010;76(14):4765-71.

(c) 2018 Uba; This is an Open Access article distributed under the terms of the Creative Commons Attribution License (http://creativecommons.org/licenses/by/4.0), which permits unrestricted use, distribution, and reproduction in any medium, provided the original work is properly cited.

Peer-review history:

The peer review history for this paper can be accessed here: http://www.sdiarticle3.com/review-history/46533 